OPEN ACCESS

Edited by:

Tara Ratnam,

Independent researcher

Reviewed by:

Hoa T. M. Nguyen,

University of New South Wales,

Australia

Elisabete dos Santos Freire, Universidade São Judas Tadeu, Brazil

${ }^{*}$ Correspondence: Jeffrey T. Olimpo jtolimpo@utep.edu

Specialty section: This article was submitted to

Teacher Education,

a section of the journal

Frontiers in Education

Received: 05 August 2021 Accepted: 01 December 2021

Published: 18 January 2022

Citation:

Esparza D, Lynch-Arroyo RL and Olimpo JT (2022) Empowering Current

and Future Educators: Using a

Scalable Action Research Module as a

Mechanism to Promote High-Quality

Teaching and Learning in STEM.

Front. Educ. 6:754097.

doi: 10.3389/feduc.2021.754097

\section{Empowering Current and Future Educators: Using a Scalable Action Research Module as a Mechanism to Promote High-Quality Teaching and Learning in STEM}

\author{
David Esparza ${ }^{1}$, Ruby L. Lynch-Arroyo ${ }^{2}$ and Jeffrey T. Olimpo ${ }^{1 *}$ \\ ${ }^{1}$ Department of Biological Sciences, The University of Texas at El Paso, El Paso, TX, United States, ${ }^{2}$ College of Education and \\ Human Sciences, The University of New Mexico, Albuquerque, NM, United States
}

Professional development in action research methods can increase educators' dispositions toward the adoption of evidence-based practices and data-based decision making. However, an in-depth review of the literature revealed that extant forms of action research professional development (ARPD) may not be accessible to all educators as they are often relegated to full-semester undergraduate and/or graduate courses, internships, and teacher education programs. To address this issue, we designed, implemented, and assessed a scalable active-learning module on action research to strengthen the cognitive and affective outcomes of prospective and inservice STEM teachers $(N=26)$ enrolled in a cross-listed Scientific Teaching course, all of whom had not previously conducted action research. This three-session module integrated case studies, collaborative practice, group discussions, and instruction on action research theory and data collection methodologies. Analysis of pre-/postintervention survey responses revealed that participants expressed greater self-efficacy related to their ability to design and conduct action research, strengthened knowledge of the process of action research, and greater awareness of the utility of data to inform research and teaching. When asked about the benefits of engaging in action research, participants suggested it could enhance their pedagogical content knowledge and reflectivity. However, participants identified logistical issues such as time constraints and resource availability, lack of institutional support, and possible student resistance to data collection as potential barriers to future action research practice. Overall, our module provides a scaffold to enculturate in-service educators to inquiry dispositions while offering a scalable approach to help prospective teachers in their transition to in-service practice.

Keywords: teacher preparation, teacher education, action research, professional development (PD), K-12, active learning 


\section{INTRODUCTION}

National science education reports have continued to call for the incorporation of evidence-based teaching strategies-such as active learning-into the K-16 curriculum [National Research Council, 2012; Next-generation Science Standards (NGSS) Lead States, 2013]. Active learning increases students' conceptual understanding in science, technology, engineering, and mathematics (STEM) courses whilst decreasing the achievement gap between minoritized students and their nonminoritized peers (Freeman et al., 2014; Olimpo and Esparza, 2020; Theobald et al., 2020). Despite the benefits of using teaching practices that support active learning, instructors cite prominent obstacles to its implementation such as large class sizes, time constraints, and overall uncertainty attributed to the looselystructured nature of student-centered instruction (Henderson and Dancy, 2011; Hains and Smith, 2012; Zagallo et al., 2019). Training in action research methods offers a mechanism to develop teachers' abilities to respond to this uncertainty and, thereby, can support instructors as they employ active-learning instructional methods and constructivist approaches (O'Connor et al., 2006). Notably, through action research, educators become active participants in their career-long professional development as they gather data to address emergent classroom issues (Eraut, 1994; Bates, 2005; Kemmis, 2010).

More acutely, action research refers to the process by which educators actively work to improve their instruction through iterative cycles of: 1) planning an intervention; 2) implementing the intervention and collecting data on its effectiveness; 3 ) observing student outcomes through data analysis; and 4) reflecting upon the successes and shortcomings of their approach (Carr and Kemmis, 1986). The use of data by educators has been found to improve student achievement and conceptual understanding, especially in schools with higher proportions of disadvantaged students (Van Geel et al., 2016; Kennedy-Clark et al., 2018). Data-based decision making likewise contributes to the advancement of the educational enterprise as a whole, supporting large-scale reform initiatives that result in policy changes at the school-, district-, and region-wide levels (Campbell and Levin, 2009). Despite the documented benefits of action research and data-based decision making, school administrators and educators often make decisions by referencing personal experience and anecdotal evidence rather than student data (Flowers and Carpenter, 2009). Moreover, science instructors can face difficulties when linking theory and practice and, therefore, may struggle to integrate action research and data use into their teaching routines (Capobianco and Feldman, 2010; Faikhamta and Clarke, 2015; Gelderblom et al., 2016). In response, action research professional development (ARPD) programs have emerged throughout the past three decades to address this concern.

Ginns et al. (2001) called for the inclusion of action research in teacher education, noting that the early enculturation of educators to action research would equip them to endure their first years of teaching by strengthening their capacities for adaptive instruction, data use, and reflection on teaching. However, there are often issues with the accessibility of such programs, as action research training is frequently relegated to under- or post-graduate internships, teacher education programs with action research requirements, (under)graduate-level action research courses, or professional development schools (Price, 2001; Levin and Rock, 2003; Hagevik et al., 2012; Yan 2017; Jakhelln and Pörn, 2019; Dassa and Nichols, 2020). Among these commonly-cited constraints imposed by such models, trainees have also noted that such experiences are difficult to participate in due to the inaccessibility of resources, materials, and institutional support, indicating issues with both the scalability and sustainability of ARPD programs (Clarke et al., 2006; Looi et al., 2006). In consideration of these factors, the present research takes a three-pronged approach in which we: 1) present a scalable and easily-implementable module with active, case-based, and collaborative exercises designed to introduce educators to action research; 2) characterize the impact of the module through defining shifts in participants' cognitive outcomes and affective dispositions toward action research; and 3) define benefits and potential barriers to participants' future engagement in action research.

Specifically, a quasi-experimental mixed methods approach was employed to address the following research questions:

1. How does engagement in the ARPD intervention influence participants' comprehension of action research theory and practice?

2. To what extent do participants' conceptualizations of the action research process shift, if at all, as a result of engagement in the ARPD intervention?

3. What impact does the ARPD intervention have on participants' attitudes toward the design, nature, and significance of action research as well as their perceived self-efficacy with respect to conducting an action research study?

4. What perceptions do participants hold regarding the potential benefits and barriers of engaging in action research?

We hypothesized that participants would experience developments in their knowledge of and affect toward action research due to the highly-interactive and scaffolded nature of the ARPD module. This assertion is corroborated by previous studies in the field, which demonstrate that ARPD initiatives can positively impact various aspects of trainees' teaching selfefficacy as well as their understanding of the relationship between action research and classroom praxis (Carboni et al., 2007; Medwell and Wray, 2014). Collectively, the findings of the current study will provide insight into both the efficacy of the intervention, as described herein, as well as formative feedback for enhancing future ARPD initiatives on a local and national scale.

\section{HISTORICAL AND EPISTEMOLOGICAL PERSPECTIVES ON ACTION RESEARCH}

The advent of action research is most attributed to Kurt Lewin, a social psychologist whose research applied social science methods 
to develop practical solutions to address social and group issues. Lewin and his students first employed action research approaches to characterize group structures in neighborhood and factory settings (Adelman, 1993). As a result of exposing individuals in these contexts to democratic vs. autocratic leadership structures, Lewin and his team documented the positive impacts of democratic leadership on productivity and collaboration whilst also demonstrating the effectiveness of action research as a form of iterative inquiry to incite change (Lewin and Lippitt, 1938; Lewin et al., 1939).

Lewin upheld a pragmatist position, famously stating that there is "no action without research; no research without action," suggesting that inquiry, knowledge production, and the design of practical solutions to solve societal problems were tightly intertwined processes (Adelman, 1993). Pragmatism is a "problem-focused" epistemological stance that emphasizes the desired solution or change over theory and antecedent knowledge (Dewey, 1905; Cherryholmes, 1992). In pragmatism, scientific inquiry involves the: 1) identification of real-world issues (e.g., students struggling with classroom content); 2) action, in which the researcher attempts to answer the research question with the desired solution in mind; and 3) consequences, where the researcher assesses the consequences of their actions (Oquist, 1978). These tenets are reflected in the definition of action research provided by Carr and Kemmis (1986) - which is employed in the present work - wherein it is described as:

“...a form of self-reflective inquiry undertaken by participants in social situations to improve the rationality and justice of their practices, their understanding of these practices, and the situations in which practices are carried about" (p. 162).

During action research, practitioners are to engage in selfreflective cycles of planning to rectify an issue identified within a teacher's practice, acting upon that plan by shifting pedagogical approaches, observing the outcomes via data collection, and reflecting upon the outcomes of the intervention to restart the cycle or identify new questions (Lewin, 1946). The pragmatist stance of action research stands in opposition to empiricism and positivism, which both conjecture that natural observation in consideration of pre-existing knowledge is the sole model of scientific inquiry (Oquist, 1978). Further, the emphasis of action research on theory and practice as interrelated entities disagrees with structuralism, which views theory and practice as secular (Eagleton, 1985).

Notably, positivist science remained the predominant mode of scientific practice throughout the 1940s into the early 1970s, resulting in waning interest in action research as a mode of knowledge production (Sanford, 1976; Carr, 1994). However, action research practice eventually rose in popularity in the late 1970s and 80s as educationalists began implementing ARPD programs for in-service teachers (Elliot and Adelman, 1976). This popularity continued into the late 20th and early 21 st centuries, where action research practice is applied in a diverse array of academic disciplines such as nursing (Munten et al.,
2010), social work (Healy, 2001), organizational psychology (Huxham and Vangen, 2003), information sciences (Nair et al., 2011), and education (Willegems et al., 2017). This coincided with an increase in the development of ARPD throughout the mid-1990s to the present day, with curricula often designed around the premise of partnering in-service teachers with university-based researchers to engage in collaborative action research (Clift et al., 1990; Altrichter et al., 1993; Valanides et al., 2003; Chin et al., 2006; Frankham and Howes, 2006; Markic and Eilks, 2006; Mitchell et al., 2009; Capobianco and Feldman, 2010; Hagevik et al., 2012).

\section{THE CURRENT STATE OF ACTION RESEARCH PROFESSIONAL DEVELOPMENT}

Action research has long been acknowledged as an effective tool for instructor PD, with programs geared toward in-service teacher engagement in action research emerging as early as the 1950s (Corey, 1953). Only recently, however, have national teaching accreditation organizations called on teacher education programs to integrate experiences that improve a teacher's proficiency in skills related to action research, such as reflection and data literacy (National Council for Accreditation of Teacher Education (NCATE), 2010; Gelfuso et al., 2015). While such experiences can lead to improvements in teachers' pedagogical knowledge and confidence in teaching, it has been argued that ARPD must be positioned earlier in teacher education programs to ensure that educators develop a disposition toward constructivism and inquiry (Crookes and Chandler, 2001; Kotsopoulos et al., 2012). Therefore, the following review focuses on novice educators-namely graduate teaching assistants, tutors, teacher candidates, pre-service teachers, and beginning teachers-and their outcomes following participation in ARPD programs.

Action research programs are often created to promote the cognitive development of educators, although those described in this review accomplished this to varying degrees of success (Willegems et al., 2017). The literature describes a variety of action research-focused courses and degree programs that were successful in imparting knowledge of action research (KNOW; Table 1) to novice teachers (Fueyo and Neves, 1995; Stevens and Kitchen, 2004; Schulte, 2017). Faikhamta and Clarke (2015), for example, implemented an upper-division action research course with concomitant action research practice to undergraduate preservice teachers enrolled in an education degree program. While trainees initially struggled to formulate research questions and did not see the utility of action research, final journal reflections indicated that they understood action research as a systematic inquiry to inform instructional change. Similar outcomes have been illustrated in undergraduate and graduate courses with integrated action research projects, in which prospective and novice teachers shifted their perceptions of action research as being purely practical to ones in which action research was viewed as an effective and organized method based in theory to improve upon practice (Smith and Sela, 2005; Carboni et al., 2007; Odhiambo, 2010). 
TABLE 1 | Literature review: Positive and negative outcomes of teacher involvement in action research.

\begin{tabular}{|c|c|c|c|c|c|c|c|c|c|c|}
\hline \multirow[t]{2}{*}{$\begin{array}{l}\text { Article and } \\
\text { Year }\end{array}$} & \multirow[t]{2}{*}{ Sample Size } & \multirow[t]{2}{*}{ Intervention Type } & \multirow[t]{2}{*}{ Duration (Months) } & \multicolumn{5}{|c|}{$\begin{array}{c}\text { Positive } \\
\text { Outcomes }^{a}\end{array}$} & \multicolumn{2}{|c|}{$\begin{array}{c}\text { Negative } \\
\text { Outcomes }^{b}\end{array}$} \\
\hline & & & & KNOW & SE & REFL & DATA & PCK & CLDF & ACCS \\
\hline Dassa and Nichols (2020) & $n=5$ & Internship & 10 & $x$ & $x$ & & $x$ & $x$ & & \\
\hline Bendtsen et al. (2019) & $n=29$ & Degree & 5 & $x$ & & & & $x$ & $x$ & $x$ \\
\hline Jakhelln and Pörn (2019) & $n=10$ & Degree & 10 & & & & & & $x$ & $x$ \\
\hline Qing-li et al. (2019) & $n=12$ & Internship & 3 & & & $x$ & & $x$ & $x$ & \\
\hline Kennedy-Clark et al. (2018) & $n=4$ & Degree & 2 & $x$ & & & & $x$ & $x$ & \\
\hline Wastin and Han (2014) & $n=1$ & - & 10 & & & & & $x$ & & \\
\hline Yan (2017) & $n=23$ & Course & 4 & $x$ & & & & & $x$ & \\
\hline Schulte (2017) & $n=70$ & Degree & 10 & $x$ & $x$ & $X$ & & & $x$ & \\
\hline Ulvik and Riese (2016) & $n=32$ & Degree & 4 & $x$ & & & & & $x$ & $x$ \\
\hline Castro-Garcés and Martínez Granada (2016) & $n=1$ & Ind. research & - & $x$ & & & & $x$ & & \\
\hline Crawford-Garrett et al. (2015) & $n=3$ & Degree & 10 & $x$ & & $\mathrm{X}$ & & $x$ & & $x$ \\
\hline Faikhamta and Clarke (2015) & $n=23$ & Degree & 10 & $x$ & $x$ & & $x$ & & & $x$ \\
\hline Medwell and Wray (2014) & $n=8$ & Ind. research & 2 & $x$ & $x$ & $x$ & & & $x$ & $x$ \\
\hline Hagevik et al. (2012) & $n=20$ & Internship & 10 & & & $x$ & & $x$ & & \\
\hline Lattimer (2012) & $n=25$ & Degree & 10 & $x$ & & $x$ & $x$ & $x$ & $x$ & $x$ \\
\hline Odhiambo (2010) & $n=27$ & Course & 4 & $x$ & $x$ & & & & & $x$ \\
\hline Halim et al. (2010) & $n=1$ & Course & - & $x$ & & $X$ & & $x$ & & \\
\hline Moran (2007) & $n=6$ & Internship & 3 & & & & & $x$ & & \\
\hline Zambo and Zambo (2007) & $n=296$ & Course & 10 & $x$ & $x$ & & & & $x$ & \\
\hline Carboni et al. (2007) & $n=15$ & Internship & 4 & $x$ & $x$ & & & $x$ & $x$ & $x$ \\
\hline Atay (2006) & $n=6$ & Course & 3 & $x$ & & & & X & $x$ & \\
\hline McDonough (2006) & $n=7$ & Course & 5 & $x$ & & $x$ & & & & $x$ \\
\hline Smith and Sela (2005) & $n=31$ & Course & 8 & $x$ & $x$ & & & $x$ & $x$ & $x$ \\
\hline Handsen and Nalder-Godfrey (2004) & - & Course & - & $x$ & & & & $x$ & & $x$ \\
\hline Stevens and Kitchen (2004) & $n=32$ & Internship & 9 & $x$ & & & & $x$ & & \\
\hline Levin and Rock (2003) & $n=5$ & Degree & 5 & $x$ & & & & $x$ & $x$ & \\
\hline Burbank and Kauchak (2003) & $n=10$ & Course & 10 & $x$ & & & & $x$ & $x$ & \\
\hline Gray and Campbell-Evans (2002) & $n=109$ & Internship & 4 & $x$ & & & $x$ & & & $x$ \\
\hline Rock and Levin (2002) & $n=15$ & Course & 5 & $x$ & & $x$ & & $x$ & & \\
\hline Price (2001) & $n=11$ & Course & 10 & $x$ & & $x$ & & $x$ & $x$ & $x$ \\
\hline Crookes and Chandler (2001) & $n=13$ & Degree & 4 & & & $X$ & & $x$ & $x$ & $x$ \\
\hline Kosnik and Beck (2000) & $n=60$ & Course & 8 & $x$ & $x$ & $x$ & & $x$ & & \\
\hline Valli (2000) & $n=15$ & Course & 5 & $x$ & $x$ & $x$ & & $x$ & & \\
\hline Gitlin et al. (1999) & $n=37$ & Degree & 5 & & & $x$ & & $x$ & & $x$ \\
\hline Fueyo and Neves (1995) & $n=60$ & Degree & 4 & $x$ & & $x$ & & $x$ & & $x$ \\
\hline Winograd and Evans (1995) & $n=48$ & Degree & 8 & $x$ & & & & & $x$ & \\
\hline \multirow[t]{2}{*}{ Gore and Zeichner (1991) } & $n=18$ & Internship & 6 & $x$ & & $x$ & & $x$ & $x$ & \\
\hline & & TOTALS (of 37) & & 30 & 10 & 16 & 4 & 26 & 19 & 17 \\
\hline
\end{tabular}

${ }^{a}$ Positive outcomes included knowledge of action research (KNOW), teaching and/or research self-efficacy (SE), capacity for reflective teaching practices (REFL), data analysis skills and data literacy (DATA), and pedagogical content knowledge (PCK).

${ }^{\boldsymbol{b}}$ Negative outcomes included collaborative differences with classmates or other teachers (CLDF) and issues of access (ACCS) to time, support, or resources.

Despite these findings, the literature also presents mixed results on the efficacy of action research-focused courses, degree programs, and internships on linking theoretical knowledge to practices (Dang, 2013). For example, Valli (2000) describes a graduate action research course designed for teacher candidates; at the end of the course, participants expressed difficulty in describing the definition and relevance of action research to their teaching practice. Similarly, Jakhelln and Pörn (2019) analyzed the collaborative action research-based theses of undergraduate teacher candidates, which revealed a misunderstanding of the action research process, a disconnect between theory and practice, and little evidence of reflection on teaching methods. When successful, however, it is apparent that instruction on action research can enhance the pedagogical content knowledge (PCK; Table 1) of educators by increasing awareness of contextual factors, knowledge of disciplinary content, and expertise in constructivist instructional methods (Shulman, 1986; Caro-Bruce and Zeichner, 1998; Gitlin et al., 1999; Moran 2007; Halim et al., 2010; Crawford-Garrett et al., 2015; Castro-Garcés and Martínez Granada, 2016).

Apart from knowledge and recognition of the utility of action research to pedagogical improvement, professional development programs that emphasize classroom research can promote positive affect in prospective and beginning educators (Zambo and Zambo, 2007). Ten (10) of 37 reviewed studies reported increases in novice teachers' self-efficacy related to their teaching and research abilities (SE; Table 1). Trainees who had designed research projects and collected data in association with a funded grant project, for example, reported improvements to their teaching self-efficacy and capacity to make instructional decisions; similar results are reported for graduate courses with an integrated action research module (Lattimer, 2012; 
Medwell and Wray, 2014). In certain programs, it is apparent that the learning of action research concepts even resulted in the development of researcher and teacher identity in pre-service educators (Burbank and Kauchak, 2003; Smith and Sela, 2005). Approximately half (16 of 37 articles) of the described interventions improved upon a participant's capacity for reflective thinking (REFL; Table 1). For instance, Gore \& Zeichner (1991) - and more recently Kotsopoulous et al. (2012)-report that teachers became acutely aware of the impact of their behaviors, pedagogical approaches, and instructional materials on student performance as a result of participating in ARPD interventions.

The implementation of action research practices is typically not required by institutions and, thus, training in action research is often only accessible through external professional development opportunities or during teacher education (Kotsopoulos et al., 2012; Qing-li et al., 2019). First, of the 34 articles that reported the program length, novice teachers were asked to spend approximately six-and-a-half months, on average, engaged in ARPD programs, with many of these interventions requiring significant out-of-class time commitment (Handsen and NalderGodfrey, 2004; Faikhamta and Clarke, 2015; Ulvik and Riese, 2016). Program length and accessibility may result in complications as these educators (who may still be students) are asked to simultaneously balance teaching fieldwork, coursework, extracurricular activities, part-time occupations, and/or full-time teaching positions in addition to their action research (Caro-Bruce and Zeichner, 1998; Crookes and Chandler, 2001; Lattimer, 2012). For example, previous efforts have integrated action research into teacher education via enrollment in a year-long program at a professional development school, where apprentice teachers are trained in action research methods by on-site mentor teachers (Rock and Levin, 2002; Levin and Rock, 2003). Similar programs have recruited university-based education researchers to train inservice teachers in both content knowledge and action research (Markic and Eilks, 2006). While effective in advancing knowledge of action research, participants of such programs expressed disdain for the time constraints imposed upon their projects, which were seen as compromising to the success of their research and teaching efforts (Levin and Rock, 2003). Moreover, the logistics of traveling to action research internships (which are usually unpaid) can act as a barrier for all teachers, but especially those teaching at rural schools (Gitlin et al., 1999; Kennedy-Clark et al., 2018).

While traditional, logistical barriers to research are present in the literature (e.g., time; proximity to study sites; difficulties obtaining a substitute), other types of obstacles can limit teacher engagement in action research. In our review, we found that 17 of 37 sources described obstacles that educators may encounter when accessing ARPD programs (ACCS; Table 1). Logistical barriers to access include the lack of resources for novice researchers to complete an action research study, inability to access a study population due to Institutional Review Board regulations, or absence of support from the institution at which the research was to be conducted (Smith and Sela, 2005; Atay 2006; Ulvik and Riese, 2016). Full immersion in ARPD and/or the action research process could similarly be obstructed by experiencing collaborative differences with classmates or other teachers, as suggested by 19 of the 37 articles reviewed (CLDF, Table 1).

Furthermore, educators can experience "skill-based" barriers to engaging in the technical and analytical components of action research practice. For example, pre-service and beginning teachers have expressed difficulty searching for and synthesizing the education research literature, citing the highly-technical language used in education research articles as inaccessible (Gitlin et al., 1999; Odhiambo, 2010). Additionally, those who participate in ARPD programs often experience difficulties aligning their data collection strategy with their study objectives and, likewise, struggle to analyze the data they collect (Gray and Campbell-Evans, 2002; Faikhamta and Clarke, 2015). Despite the prevalence of trainee involvement in data collection during ARPD programs, instruction on data collection and analysis is not usually offered as part of these programs, and subjects in only four of 37 articles reported increased capacity to analyze and interpret data (DATA; Table 1). Given the dataintensive focus of action research, these findings suggest a need for ARPD programs to integrate instruction on the respective strengths and weaknesses of quantitative and qualitative methods to encourage alignment between the data collected and the objectives of an action research study as well as to minimize the "skill-based" barriers to engaging in action research.

As evidenced by this review of the literature, cognitive (e.g., understanding of action research) and affective (e.g., teaching self-efficacy) teacher outcomes improve upon engagement in ARPD opportunities. Despite these findings, more than half of the reviewed papers described barriers that may prevent teachers from accessing and/or wholly participating in all components of ARPD opportunities (e.g., distance from a professional development school; difficulties finding a substitute). Furthermore, barriers persist even after teachers gain access to ARPD opportunities, as participants are often faced with time constraints (e.g., balancing teaching and research), the general absence of institutional and administrative support as they begin conducting action research, and "skill-based" challenges (e.g., lack of scientific literacy; data analysis skills). The results of this literature review highlight an explicit need for the creation of accessible ARPD experiences that develop instructors' knowledge and awareness of action research as a tool for educational change. The intervention described herein aims to accomplish this goal through the implementation of a scalable, low-cost, three-session workshop on action research intended to introduce prospective and in-service STEM teachers to the: 1) underlying theory and purpose of action research; 2) strengths and weaknesses of various action research approaches; and 3) the significance of action research to teaching and learning within the STEM disciplines.

\section{MATERIALS AND METHODS}

\subsection{Participant Recruitment and Research Design}

Participants were students $(N=26)$ enrolled in a cross-listed Scientific Teaching course, spread across two cohorts-one in the 
TABLE 2 | Demographic characteristics of action research module participants.

\begin{tabular}{lc}
\hline Category & Participants (\%) \\
\hline Class Standing & \\
Freshman & 0.0 \\
Sophomore & 0.0 \\
Junior & 3.8 \\
Senior & 50.0 \\
Graduate & 46.2 \\
Major & \\
Biological Sciences & 73.3 \\
Geological Sciences & 3.8 \\
Forensic Science & 7.6 \\
Engineering & 11.5 \\
Mathematics & 3.8 \\
Gender & \\
Male & 34.6 \\
Female & 65.4 \\
Teaching Experience & \\
Primary (K - 5) & 19.2 \\
Middle (6 - 8) & 26.9 \\
Secondary (9 - 12) & 38.5 \\
Postsecondary & 26.9 \\
Test Preparation/Tutoring & 26.9 \\
No Experience & 30.8 \\
\hline aDoes not total to 100\%, as participants possessed diverse teaching experiences and \\
were thus able to select multiple options
\end{tabular}

spring of 2017 and another in the spring of 2019. In aggregate, participants were equal parts undergraduate and graduate students enrolled in STEM majors/programs at a Southwestern, research-intensive, Hispanic-Serving Institution. Roughly $30 \%$ of all participants $(n=8)$ lacked any form of teaching experience, with the remainder of participants representing diverse teaching backgrounds in K-16 contexts including test preparation, tutoring, and peer-led team learning (Table 2).

\subsection{Description of the Action Research Module}

We employed constructivist approaches to develop a threesession curricular intervention (180 min of total instruction) that exposed participants to action research concepts (Table 3). During the first session, we held a brief interactive lecture (Supplementary Appendix S1.1)accompanied by a graphic organizer (Supplementary Appendix S1.2) - to introduce our participants to action research. Following, participants were engaged in an active "Design an Action Research Study" exercise (Supplementary Appendix S1.3), in which they were able to select from three cases describing common classroom issues, discuss a plan to address this issue, select fitting methodological approaches (e.g., surveys; interviews), and interpret mock data corresponding to their questions. We purposefully structured this activity to emulate the process of inquiry and to reinforce the appropriate methodologies for conducting action research such as study design, mixed methods data collection, data interpretation, iteration, and dissemination. Students were asked to work in teams of 4-5 to encourage discussion of action research methods and promote collaborative problem-solving amongst groups. In the final session of the workshop, we integrated concept mapping and group discussion techniques throughout the "gallery walk" section of the module, which allowed participants to constructively analyze similarities and differences between their conceptions of action research.

\subsection{Instruments and Data Analysis}

To explore participants' developments in the cognitive and affective domains following engagement in our intervention, we administered a series of surveys in a pre-/post-module format. Descriptive and frequency statistics were calculated using SPSS (v.25, IBM). Where appropriate, paired t-tests with accompanying measures of effect size (Cohen's $d$ ) were conducted to detect shifts in participant outcomes. The study was approved by The University of Texas at El Paso's Institutional Review Board under protocol ID No. 1002489. Survey instruments and specific methods of analysis are described below.

\subsubsection{Action Research Content Quiz}

The Action Research Content (ARC) quiz is a multiple-choice, 10 -question assessment designed to measure teachers' knowledge of action research before and after participation in the module. All questions were created in-house, based on Mills (2000) Action research: A guide for the teacher researcher, which reviews the core concepts, theoretical grounding, and potential utility of action research as a classroom resource. Questions can be found in Supplementary Appendix S2.1.

\subsubsection{Attitudes Toward Education and Action Research Questionnaire}

To complement the action research quiz, we designed and administered the Attitudes Toward Education and Action Research (ATEAR) questionnaire. The ATEAR is a 22 -item student assessment of learning gains (SALG) survey used to capture participants' affect toward the nature and overall significance of action research. The ATEAR includes statements to evaluate participants' self-efficacy and confidence in conducting action research, attitudes on who may be the focus of an action research project, and attitudes toward the use of quantitative/qualitative methods in action research. To maintain alignment with previously published instruments, we integrated items from the work of Taruc (2016) and Morales et al. (2016), which were modified to fit the format of standard SALG items. Participants were asked to record their responses to the assessment on a 5-point Likert scale ranging from strongly disagree (" 1 ") to strongly agree (“5”). Face equivalence was used to categorize the subscales of the ATEAR rather than factor analysis, given our minimal sample size (Taber, 2018). We further examined the Cronbach's a values for the ATEAR, which indicated moderate to excellent internal consistency for the overall instrument ( $\alpha_{\text {pre }}=0.836, \alpha_{\text {post }}=0.912$ ) and amongst its subscales $\left(\alpha_{\text {pre }}=0.587-0.856, \alpha_{\text {post }}=0.679-0.864\right)$. While these values indicate the reliability of the ATEAR, we applied 
TABLE 3 | Module learning objectives and lesson plan.

\section{Module Learning Objectives}

By the end of the module, participants should be able to...

Identify the purpose, theoretical underpinnings, and strategies characteristic of action research practice

Generate potential research designs and evaluate the strengths and weaknesses of such approaches theoretically and with respect to their own teaching context Describe how action research relates to scientific teaching and to teaching and learning more broadly

\section{Summary of Module Tasks/Actions}

Session 1: An Introduction to Action Research ${ }^{\mathrm{a}}$

1. Introduction to Action Research presentation ( $50 \mathrm{~min})$

\section{Description}

- Active, discussion-based lecture (Supplementary Appendix S1.1) in which participants are introduced to the Lewin (1944a); Lewin (1944b) theoretical framework of action research and common foci of action research projects in education

- Participants complete a graphic organizer (Supplementary Appendix S1.2) during the lecture to document and organize the content of the presentation

\section{Session 2: Conducting Action Research ${ }^{b}$}

1. Review of the moments of action research and discussion of qualitative and quantitative research methods ( 20 min)

2. Design an Action Research Study group activity ( 60 min)

3. Whole-group discussion on action research to enact change in science education and society ( $10 \mathrm{~min})$

\section{Description}

- A brief lecture to remind participants of the 'moments' of action research (plan act, observe, reflect), the foci of action research, and a brief discussion on ways to collect quantitative (e.g., surveys) and qualitative (e.g., open-response question) data from students

- A "choose your own adventure"-style activity (Supplementary Appendix S1.3) where participants work in teams to conduct one of three action research studies, each based on a hypothetical classroom problem/school issue

- Participants select methods to approach the research questions (qualitative, quantitative, or mixed methods)

- Participants interpret hypothetical data
Session 3: Action Research, Science, and Society ${ }^{\text {ab }}$

1. Design an Action Research Study group activity ( 20 min)

2. Mapping Out Action Research Gallery Walk group activity ( 20 min)

\section{Description}

- Participants are provided with time to finalize their action research study

- Participant groups share the action research design and outcomes that emerged from the hypothetical study that they performed in the Design an Action Research Study activity via a concept map drawn on a whiteboard

- Participants engage in a "gallery walk" activity to view and provide feedback on all concept maps

- A brief, whole-class discussion on commonalities and differences between each groups' flowcharts and on the ways action research practice might be leveraged to promote changes in policy and practice in science education and society, overall

aThe pre-intervention and post-intervention assessments ( 30-min each) were administered in the first and third (final) sessions of the module, respectively.

${ }^{b}$ Please note that, although not explicitly stated in the table, the "Introduction to Action Research" PowerPoint presentation (Supplementary Appendix S1.1) should be used to facilitate various activities found in the second and third sessions.

the Bonferroni method during analysis to correct $p$-values for multiple comparisons across the ATEAR subscales and minimize the risk for type 1 errors.

\subsubsection{Action Research Flowchart Assessment}

The action research process is considered dynamic, as opposed to a series of concrete steps. Putting aside positivist assumptions, the process of action research is not wholly dissimilar to the scientific process in which iteration, unpredictability, and adaptability are commonplace (Aguinis, 1993). To obtain a thorough understanding of participants' views of the action research process, we asked them to complete the Action Research Flowchart Assessment (ARFA) - a modified version of the Scientific Process Flowchart Assessment (SPFA; Wilson and Rigakos, 2016). The ARFA (Supplementary Appendix S2.2) allows for the visualization of changes in participants' cognitive representations of the action research process-a feature that multiple-choice questions lack (Novick, 2001; Burkhard, 2005; Smith et al., 2013; Tversky, 2014; Zvauya et al., 2017). Participants were asked to construct a flowchart that most accurately represented their perception of the action research process, including: 1 ) generalized steps of the action research process; 2) factors that make for a good action research project; 3) reasons for doing action research; and 4) what action research influences and, in turn, what it is influenced by. The instrument allows for participants to assemble interconnected and tiered visualizations that represent their mental model of the action research process (Wilson and Rigakos, 2016). Likewise, the ill-structured prompt allows participants to connect their model in such a way that denotes flow and clarifies how they view relationships between action research concepts, similar to concept maps (Markham et al., 1994). 
Responses to the assessment were scored using a similarly modified version of the SPFA scoring criteria (Supplementary Appendix S2.2). The categories to score flowchart connectivity and interconnectivity remained unchanged, while the intermediary categories were modified to measure: 1) action research project design competence; 2) the reasons for doing action research; and 3) the nature of action research. The creation of such categories was informed by Mills (2000) Action research: A guide for the teacher researcher and reviews of the use of action research in K-16 contexts (Womack, 1997; Cochran-Smith and Lytle, 1999; Willegems et al., 2017). All ARFA responses were blinded and scored by two individuals with expertise in biology education (D.E. and J.T.O.). Strong interrater reliability was observed $(\kappa=0.911 ; p<0.001)$, with all disputes resolved through discussion between the coders. Paired t-tests were subsequently used to assess participants' performance on each of the five categories represented in the rubric as well as their holistic score (representing their overall knowledge and understanding of the action research process).

\subsubsection{Open-Ended Prompts}

Instruction in action research is offered less often to beginning teachers relative to instances in which it is designed for experienced teachers (Holm et al., 1999; Ginns et al., 2001). We were therefore curious about the professional benefits and perceived barriers that prospective and in-service educators within our sample associated with conducting action research. We asked participants two open-ended questions following completion of the intervention: 1) What long-lasting effects, if any, do you believe conducting an action research project would have on your professional career? and 2) What potential problems/difficulties would you anticipate encountering if you were to engage in action research, and how would you resolve them? Written responses to these questions were coded using a descriptive-interpretive approach, with emergent themes identified following iterative cycles of open and axial coding (Tesch, 2013). Each response was coded independently by two researchers (D.E. and J.T.O.) with advanced experience in biology education. Strong interrater reliability was observed between coders $(\kappa=0.870 ; p<0.001)$, with all disputes resolved via discussion between the coders. Frequency statistics for each code are presented to provide indices of the commonality of responses, with an aggregate list of exemplar quotes likewise included for each theme.

\section{RESULTS}

\subsection{Participants Gained a Greater Understanding of Action Research}

We initially hypothesized that we would observe an increase in participants' understanding of action research concepts such as knowledge of the cyclic nature of action research and identification of the types of data that could be collected.
Paired $t$-test analysis indicated a significant increase $[t(25)=$ 4.960; $p<0.001]$ in participants' pre-intervention $\left(M_{\text {pre }}=4.62\right.$, $S D=1.47)$ to post-intervention $\left(M_{\text {post }}=5.96, S D=1.51\right)$ ARC quiz scores, with a large effect size observed (Cohen's $d=0.97$ following adjustment for paired data).

\subsection{Impacts of the ARPD Module on Participant Affect Toward Action Research} In facilitating this action research module, we were focused on strengthening participants' affective dispositions toward action research practice. In analyzing responses to the ATEAR, we found improvements to participants' attitudes toward action research as well as prominent ceiling effects that persisted from the beginning to the end of the module (Table 4). We observed significant increases in students' agreement with the purpose of action research practice as well as in their appreciation for the importance of reflection as part of the action research process. Moreover, participants strongly agreed with statements suggesting that "action research investigates issues of practical importance" and that it is a "valuable way to improve teaching and learning," demonstrating that the module was successful in imparting the significance of action research onto participants. Despite these increases, we observed a ceiling effect on the collaboration item isomorphic to what was seen in the ARC quiz, suggesting that participants valued the role of collaboration in research similarly both before and after completing the action research module. Otherwise, we observed a significant increase in participants' attitudes toward the importance of issues investigated by action research, with strong agreement to the statements that action research can improve both teaching and learning as well as contribute to curriculum and institutional improvement likewise being observed (Table 4).

In our sample, participants strongly agreed that action research required time investment on both the pre- and post-ATEAR. The literature presents several examples of instructor resistance to action research practice due to time constraints and lack of support from both teacher educators and institutions (Winograd and Evans, 1995; Lattimer, 2012; Ulvik and Riese, 2016; Bendtsen et al., 2019). As such, we designed this module with explicit attention toward strengthening participants' confidence in their ability to conduct action research in the face of such obstacles. Analysis of the "self-efficacy" portion of the ATEAR revealed that the module was effective in accomplishing this goal, with significant increases noted in current and future educators' confidence in their aptitude to independently develop and implement action research projects in their own classrooms as well as in their knowledge of action research practice.

Most action research programs detailed in the literature require teachers to design experiments and collect and analyze their own data (Qing-li et al., 2019). However, few ARPD programs center on increasing teachers' positive attitudes toward data collection and analysis. Our module emphasized these skills and, following participation in our program, participants exhibited statistically significant increases in their awareness of the foci of action research projects as well as in the utility of qualitative and quantitative approaches. Results indicate that participants entered the module cognizant of the fact that 
TABLE 4 | Attitudes Toward Education and Action Research (ATEAR) - SALG assessment results.

\begin{tabular}{|c|c|c|c|}
\hline Category & $\begin{array}{l}\text { Pre-Module } \\
\text { M (SEM) }\end{array}$ & $\begin{array}{l}\text { Post-Module } \\
\text { M (SEM) }\end{array}$ & $p$-value \\
\hline \multicolumn{4}{|l|}{ Nature of Action Research ${ }^{a}$} \\
\hline Education/Action research is problem-focused & $3.31(0.14)$ & $4.12(0.16)$ & $<0.001$ \\
\hline Teacher reflection is part of education/action research & $3.85(0.23)$ & $4.46(0.15)$ & 0.003 \\
\hline Collaboration is important in education/action research & $4.58(0.13)$ & $4.65(0.10)$ & 0.425 \\
\hline Education/Action research requires a time commitment & $4.54(0.11)$ & $4.54(0.10)$ & 1.000 \\
\hline \multicolumn{4}{|l|}{ Significance of Action Research ${ }^{\mathrm{b}}$} \\
\hline Education/Action research investigates issues of practical importance & $4.15(0.14)$ & $4.62(0.10)$ & 0.003 \\
\hline Education/Action research is a valuable way to improve teaching and learning & $4.27(0.11)$ & $4.54(0.13)$ & 0.070 \\
\hline Education/Action research enhances school/curriculum improvement & $4.46(0.14)$ & $4.54(0.15)$ & 0.574 \\
\hline \multicolumn{4}{|l|}{ Action Research Self-Efficacy ${ }^{c}$} \\
\hline I feel that I can independently develop education/action research experiments & $2.81(0.23)$ & $4.04(0.18)$ & $<0.001$ \\
\hline I am confident in my knowledge of education research design & $2.50(0.19)$ & $3.96(0.14)$ & $<0.001$ \\
\hline I feel confident in my ability to conduct education/action research in my classroom & $2.85(0.22)$ & $4.12(0.14)$ & $<0.001$ \\
\hline Education/Action research is intimidating & $3.04(0.19)$ & $2.58(0.22)$ & 0.056 \\
\hline I would consider myself a teacher-researcher & $3.00(0.24)$ & $3.42(0.20)$ & 0.009 \\
\hline \multicolumn{4}{|l|}{ Potential Foci of Action Research Projects ${ }^{a}$} \\
\hline Students can be the focus of education/action research projects & $4.15(0.12)$ & $4.42(0.17)$ & 0.129 \\
\hline Instructors can be the focus of education/action research projects & $4.00(0.15)$ & $4.46(0.19)$ & 0.005 \\
\hline Schools/institutions can be the focus of education/action research projects & $3.92(0.18)$ & $4.50(0.16)$ & $<0.001$ \\
\hline $\begin{array}{l}\text { An action research project can focus on more than one type of research subject (e.g., both teacher- and } \\
\text { student-focused) }\end{array}$ & $4.35(0.14)$ & $4.62(0.13)$ & 0.070 \\
\hline \multicolumn{4}{|l|}{ Quantitative Research Methods in Action Research ${ }^{\mathrm{b}}$} \\
\hline Quantitative methods (e.g., statistics) are important to education/action research practices & $4.03(0.13)$ & $4.50(0.14)$ & 0.008 \\
\hline Quantitative methods (e.g., statistics) are important to classroom instruction & $3.69(0.13)$ & $4.31(0.14)$ & 0.004 \\
\hline $\begin{array}{l}\text { Having knowledge of quantitative methods (e.g., statistics) makes me feel more confident in my teaching } \\
\text { abilities }\end{array}$ & $3.69(0.17)$ & $4.12(0.17)$ & 0.025 \\
\hline \multicolumn{4}{|l|}{ Qualitative Research Methods in Action Research ${ }^{\mathrm{b}}$} \\
\hline Qualitative methods (e.g., coding open-ended data) are important to education/action research practices & $4.11(0.15)$ & $4.58(0.13)$ & 0.003 \\
\hline Qualitative methods (e.g., coding open-ended data) are important to classroom instruction & $4.00(0.14)$ & $4.50(0.13)$ & 0.003 \\
\hline $\begin{array}{l}\text { Having knowledge of qualitative methods (e.g., coding open-ended data) makes me feel more confident in } \\
\text { my teaching abilities }\end{array}$ & $3.61(0.18)$ & $4.31(0.13)$ & 0.002 \\
\hline
\end{tabular}

${ }^{a}$ For these groups of items, the Bonferroni adjusted a equals 0.0125. The p-value for those comparisons that are statistically significant is bolded.

${ }^{b}$ For these groups of items, the Bonferroni adjusted a equals 0.0167 . The p-value for those comparisons that are statistically significant is bolded.

${ }^{c}$ For this group of items, the Bonferroni adjusted a equals 0.010 . The p-value for those comparisons that are statistically significant is bolded.

most action research projects are student-focused. However, we observed significantly-strengthened agreement in participants' views of the potential of action research to address issues of instructor development and institutional reform. Regarding data awareness, participants exhibited statistically significant increases in their agreement with respect to the importance of both qualitative and quantitative methods to action research projects and teaching practices (Table 4). This agreement did not wholly translate to confidence, however, as we observed that participants derived significantly greater confidence from qualitative but not quantitative methods experience.

\subsection{Participants' Cognitive Representations of the Action Research Process Became More Holistic and Cyclic}

In addition to instruction on how to link theory and practice, we sought to educate participants about the structure and process, nature, and overall broader relevance of action research practice. In our analysis of participant responses to the ARFA, we found that participants gained a greater concept of the design of action research projects, with significant increases in their pre-module to post-module performance on both the item and rating score in the "Action Research Project Design" category of the ARFA (Table 5). This is particularly encouraging given the module's emphasis on the structure and "moments" of action research as well as the types of data that can be gleaned from action research projects. We observed a similar and statistically significant increase in participants' item and rating scores for the "Nature of Action Research" category. Here, participants often highlighted the cyclic and flexible nature of action research. Further, they also put forward reasons that went beyond the classroom such as education policy reform and the critical role that dissemination plays in encouraging institutional change. Despite the considerations of the broader impacts of action research on education systems, however, 
TABLE 5 | Student performance on the Action Research Flowchart Assessment (ARFA).

\begin{tabular}{|c|c|c|c|c|c|c|}
\hline \multirow[t]{2}{*}{ ARFA Construct } & \multicolumn{3}{|c|}{ Item Score } & \multicolumn{3}{|c|}{ Rating Score } \\
\hline & $\begin{array}{c}\text { Pre-Module } \\
\text { M (SEM) }\end{array}$ & $\begin{array}{l}\text { Post-Module } \\
\text { M (SEM) }\end{array}$ & $p$-value ${ }^{b}$ & $\begin{array}{c}\text { Pre-Module } \\
\text { M (SEM) }\end{array}$ & $\begin{array}{c}\text { Post-Module } \\
\text { M (SEM) }\end{array}$ & $p$-value ${ }^{b}$ \\
\hline Connectivity & $7.23(1.30)$ & $8.58(0.92)$ & 0.303 & $2.12(0.24)$ & $2.50(0.15)$ & 0.096 \\
\hline Action Research Project Design & $4.85(0.63)$ & $7.31(0.51)$ & 0.001 & $1.19(0.18)$ & $1.89(0.15)$ & 0.001 \\
\hline Reasons for Doing Action Research & $0.39(0.15)$ & $0.65(0.24)$ & 0.337 & $1.08(0.16)$ & $1.50(0.17)$ & 0.069 \\
\hline Nature of Action Research & $0.81(0.21)$ & $1.65(0.33)$ & 0.009 & $1.27(0.15)$ & $1.85(0.14)$ & 0.001 \\
\hline Interconnectivity ${ }^{a}$ & - & - & - & $1.31(0.20)$ & $2.46(0.22)$ & $<0.001$ \\
\hline Total Score & $13.27(2.01)$ & $18.19(1.71)$ & 0.025 & $6.96(0.77)$ & $10.19(0.40)$ & $<0.001$ \\
\hline
\end{tabular}

${ }^{a}$ The interconnectivity metric does not include an item score, as per the rubric.

${ }^{b}$ The $\mathrm{p}$-values for those comparisons that are statistically significant are bolded.

participants rarely acknowledged the broader motivations of instructors to conduct action research. Overall, participants achieved a 'naïve' level in the pre-to post-module item and rating scores related to the "Reasons for Doing Action Research" criterion of the ARFA (Table 5). When considered by participants, however, certain motivations for instructor engagement in action research included strengthening student outcomes and developing their own (i.e., the respondent's) capacity for teaching.

Of note is the change in participants' cognitive representations of the action research process throughout the module. As described earlier, action research is a cyclic process-the "moments" of which involve planning, acting, observing, and reflecting-used to resolve classroom issues (Kemmis et al., 2013). The "moments" of the cycle, however, must not be viewed as a set of predefined steps but rather components of a broader dynamic process that complements the non-linear nature of classroom issues (Kemmis et al., 2013). While no significant change in item nor rating score was documented with respect to connectivity (i.e., the number of arrows used), we observed significant changes in the "interconnectivity" metric. Initially, participants primarily represented the action research process in a way that was linear, disconnected, and lacked the four "moments" of action research (plan, act, observe, reflect; Lewin, 1946). Following the module, participant depictions of the action research process were frequently circular, with, for example, lines often interconnecting the "observe" bubble to that of the "act" bubble, suggesting that they were conceptualizing iteration as part of the dynamic action research process.

\subsection{Participants Reported Positive Beliefs About the Career Benefits of Engaging in Action Research Practices}

To examine the benefits associated with their engagement in conducting action research studies in the future, we probed participants about the impact that action research might have on their career-long professional development (Table 6). Here, approximately $73 \%$ of participants provided responses related to the improvement of their pedagogical content knowledge
(Shulman, 1986). Participant responses included themes related to increased understanding of pedagogy (e.g., curriculum development), content knowledge, and awareness of contextual factors that might impact their students' learning outcomes to, ultimately, create a productive and effective learning environment. Moreover, participants $(23 \%)$ noted that action research would make them cognizant of their strengths and weaknesses as a teacher, which they could then amend through engagement in subsequent action research cycles. Pertinently, $19 \%$ of the participants signified that the use of action research in their classroom could also impact student understanding of course material and isolate teaching techniques that could appropriately address students' misconceptions. Some participants expressed goals that were broader in nature and expanded beyond both the classroom and institutional level, with responses (15\%) suggesting that the use of action research could eventually bring about amendments to educational policy on a "local" and "global" scale. Finally, a subset of participants in our sample identified the value of collaborative practice to action research, suggesting that teaching improvement and educational reform could propagate more effectively as a result of collaboration with other instructors, stakeholders, and/or institutional representatives.

\subsection{Novice Action Researchers Anticipate Using Collaboration and Study Design Alterations to Address Challenges Associated With Implementing Action Research}

In addition to the perceived benefits afforded by action research, we also asked participants what solutions they viewed as being effective to address the difficulties they anticipate facing when conducting action research projects (Table 7). The most prominent solution proposed (35\% of respondents) was to collaborate with other instructors, university-based faculty, and administrative staff. Respondents believed that, through collaboration, they could solve issues related to the design of their study, lack of resources, and absence of support and guidance. Interestingly, a related theme emerged from a subset of the responses (15\%) that focused on the 
TABLE 6 | Emergent themes from participants' responses to the question: "What long-lasting effects, if any, do you believe conducting an action research project would have on your professional career?"

Theme: Enhancing integrated PCK

Percentage of responses within theme: $73^{\mathrm{a}}$

Sample responses

- "Action research would help me gain publications and better understand the way students think."

- "It would help me with professional and curriculum development, improve my research planning, and better understand my students' mindset, opinions, and perceptions."

- "It will allow me to become a better teacher by knowing how to identify problems in my classroom, how to create a plan to solve those problems, and create a better learning environment for my students."

Theme: Increasing Reflective Practices

Percentage of responses within theme: 23

Sample responses

- "It would make me a better teacher who is aware of my mistakes and is working to improve them."

- "It would grant insight to my downfalls, thus granting criticism necessary to better my own career."

- "I would be able to see my strengths and weaknesses by conducting an action research project. I would also develop skills that I would not learn elsewhere. It would improve my ways of teaching and techniques."

Theme: Improving Student Learning Outcomes

Percentage of responses within theme: 19

Sample responses

- "Action research would allow me to improve issues that my students currently have with the material."

- "It would allow me to assess how various teaching techniques can impact student retention of information and interest in subjects so I can be a more effective educator."

Theme: Inciting Educational Change Percentage of responses within theme: 15

Sample responses

- "In addition to improving my teaching and students' learning, I could also potentially bring about changes in policy to improve education at different levels."

- "It could potentially make me a lot more aware and able to change things from a local to global level."

Theme: Collaboration

Percentage of responses within theme: 8

Sample responses

- "Education reform is a valuable effect. It starts in a classroom and through collaboration it spreads."

- "It allows me to become a better instructor and develop more effective lessons. It also increases awareness for instructors, institutions, and other stakeholders."

${ }^{a} \mathrm{~N}=26$; responses were assigned multiple themes, as appropriate, depending upon the content of the response.

explanation of action research practices to address potential collaborative differences with colleagues and also to gain approval from other teachers who may be skeptical of action research. Otherwise, some participants raised concerns about the potential for student resistance to data collection during action research. For, example, one participant stated that:

"A difficulty could be the data and actually getting students to truthfully participate. Various methods of surveying (data collection), pre-/post-surveying, extra credit could be used to help with non-compliant students."

In addition to collaboration, participants expressed that they could solve study design issues through the incentivization of surveys via extra credit, repeated sampling, and longitudinal studies (7\%). Lastly, some participants $(31 \%)$ suggested that, by using planning and time management strategies, they could circumvent the time constraints commonly experienced by teacherresearchers. Here, they suggested that the explicit allocation of class time for research and assessment, setting realistic goals while designing action research projects, and scheduling could help make action research more manageable.

\section{DISCUSSION}

Action research professional development supports educators' ability to engage in data-based decision making and encourages the use of reflective practices in the classroom to enact positive change. There are many avenues by which teachers can gain action research experience, although access to such opportunities is often contingent upon available resources (e.g., money; time), enrollment status (e.g., graduate program; internship), and location of the school (e.g., remote) in which they teach (Goodnough, 2003; Buczynski and Hansen, 2010; Allen et al., 2011; MittonKukner et al., 2015; Hillman, 2016). Relatedly, few studies have investigated the response of both pre-service and beginning teachers to action research, with most work in the field focusing on training more senior teachers in action research methodologies (Holm et al., 1999; Ginns et al., 2001; Carboni et al., 2007). Therefore, the goals of the research described in this article were threefold, in which we offer a scalable educational module designed to enculturate prospective and in-service teachers in action research, present the impact of the intervention on participant outcomes, and characterize participants' perceived benefits of and barriers to conducting action research after the module. Ultimately, we 
TABLE 7 | Emergent themes from participants' responses when asked the question: "What potential problems/difficulties would you anticipate encountering if you were to engage in action research, and how would you resolve them?

Theme: Collaboration

Percentage of responses within theme: $35^{\mathrm{a}}$

Sample responses

- "Should I have a small sample of students to test my hypothesis, I can collaborate with other instructors to compensate."

- "Resource availability and sample size are challenges. I would ask my administration to help with providing resources and collaborate with a professor to acquire an adequate sample size."

- "The lack of help, support, and resources would be difficult. I would ask for guidance and help from my superiors."

Theme: Planning and Time Management Strategies

Percentage of responses within theme: 31

Sample responses

- "In general, time may be a problem when doing action research. Given, I would plan time within the classroom to do evaluations, assessments, etc."

- "I think keeping the questions and scope manageable would help me quickly and effectively carry out research and make change. I would spend more time in planning or doing pilot studies to assess my research ideas."

- "Time management would be difficult. I will solve this problem by creating detailed schedules on when and how to conduct my research."

Theme: Discussing and Explaining Action Research

Sample responses

- "Problems with fellow colleagues when you disagree on a topic. The best way to resolve it is to discuss the issue."

- "Getting the approval and collaboration from other teachers; l'd bring examples and data that support my research question."

Theme: Accounting for Bias in Action Research Percentage of responses within theme: 7

Sample responses

- "I would resolve any issues by adjusting the study to fit whatever resources I have available. To solve time conflicts and small groups of students, I might have to conduct the study for more than one school year (several) or invite other teachers in the study as well."

- "A difficulty could be the data and actually getting students to truthfully participate. Various methods of surveying (data collection), pre-/post-surveying, extra credit could be used to help with non-compliant students."

${ }^{a} \mathrm{~N}=26$; responses were assigned multiple themes, as appropriate, depending upon the content of the response.

observed marked increases in participants' affect, awareness of the utility of data to their teaching practice, and knowledge of action research design and methods.

\subsection{Increased Affect Toward Action Research Increases Teacher Preparation and May Decrease Attrition}

The United States currently faces a severe and growing shortage of teachers, with teacher turnover among the most salient reasons for the growing demand (Garcia and Weiss, 2019). Nationally, approximately $8 \%$ of educators-or nearly 240,000 teachers annually-will depart from their teaching positions due to dissatisfaction with teaching, unsupportive administration, or negative working conditions (Carver-Thomas and DarlingHammond, 2017; Sutcher et al., 2019). Approximately 66\% of annual teacher turnover in the United States is due to preretirement departures, with nearly one-third of educators leaving within the first three years of teaching (National Commission on Teaching and America's Future, 2003; Sutcher et al., 2019). The present research showed significant increases in participants' self-efficacy associated with the design and implementation of action research projects as a result of participation in our intervention. Increased teaching self-efficacy relating to reflection, knowledge of classroom management, and pedagogical aptitude has been linked to decreased intent to leave the profession and increased student performance (Mojavezi and Tamiz, 2012; Wang et al., 2015). Likewise, increased self-efficacy in the above areas has been correlated with teacher commitment and retention within the profession (Yost, 2006; Chesnut and Cullen, 2014). Based on the results of our study, the action research module is effective in augmenting participant affect, potentially decreases the skill-based barriers that prevent teachers from engaging in action research (e.g., lack of familiarity with data collection/analysis approaches), and can possibly serve as a scaffold to aid in teacher retention.

\subsection{Awareness of Data Use Can Support Student Outcomes}

As K-16 science education reform efforts continue to emphasize the use of evidence-based practices, it is imperative to train educators to collect and use data to guide instructional decisions (NGSS Lead States, 2013; NRC 2012). Both teachers and school officials often use personal anecdotes-instead of student data and feedback-to make decisions on policy and pedagogy (Flowers and Carpenter, 2009). Training in action research, however, can facilitate the development of data literacy and awareness, which, in turn, can support data-based decision making in the classroom (Faikhamta and Clarke, 2015; Dassa and Nichols, 2020). In the present research, participant responses to the ATEAR suggested greater awareness of the 
importance of data collection to research and teaching. These increases were likely mediated by the sections of the module that emphasized methods of data collection and analysis, such as the "Introduction to Action Research" presentation (Supplementary Appendix S1.1) and the hypothetical data that participants were asked to interpret during the "Design an Action Research Study" exercise (Supplementary Appendix S1.3). Our results, overall, suggest that the module positively impacted participants' attitudes regarding the importance of data collection for research and curriculum design purposes. It can be posited that positive dispositions toward the utility of data may contribute to teachers' receptiveness to collect data from their students to inform instructional reform. This, in turn, can serve to develop teachers' pedagogical knowledge whilst augmenting student achievement (van Geel et al., 2016).

\subsection{Increased Knowledge of Action Research Can Address "Survival Mindset"}

Educators face many difficulties upon initial entry into the teaching profession. When establishing their practice, teachers are tasked with crafting lesson plans, managing scarce supplies, deciphering school norms, and learning how to manage a classroom (Veenman, 1984). Consequently, beginning teachers often express a "survival mindset" in which concerns of how to get through the day take precedent over pedagogical improvement (Katz, 1972). As such, it may seem counterproductive to engage beginning teachers in action research if it only adds to their already-large workload. However, action research addresses many of the initial struggles experienced by beginning teachers and empowers them to systematically examine their practice while learning more about the relationship between their teaching and students' behaviors and outcomes (Wastin and Han, 2014). As evidenced by analysis of the ARC and ARFA data, participants in our study exhibited strengthened knowledge of action research practice as well as a greater understanding of the design and application of action research. Studies have highlighted that knowledge in action research can improve the employability of teachers upon entry into the job market (Schulte, 2017). Likewise, knowledge of action research practice can facilitate positive attitudes toward school-wide collaborative practices and the formation of learning communities, thereby strengthening teaching practices and student achievement at the institutional level (Darling-Hammond, 2008; Vescio et al., 2008; Schulte 2017). Even in situations where teachers do not engage in further action research, they report using the skills learned during ARPD—such as reflection-during their daily practice (McDonough, 2006). The results of the present research indicate an increased understanding of the linkage between theory and practice, which can assist novice action researchers and educators at all levels in overcoming "survival mindset" by developing their capacity for assessment design and adaptive teaching.

\subsection{The Perceived Benefits of Action Research Practice}

To the best of our knowledge, no previous studies have defined the perceived advantages or constraints that, respectively, encourage or prevent teachers from ever engaging in action research. The present research found that participants perceived that-should they engage in action research practice following the module-they would see improvements in their pedagogical content knowledge (PCK), capacity to reflect on data to inform future teaching methods, and opportunities for collaboration, which would mediate increases in student performance. Possessing PCK and an understanding of action research helps educators assess the impacts of the unique contextual factors within their classroom, their understanding of the material, and instructional methods on student outcomes (Shulman, 1986). An improved awareness of contextual factors and student needs is well documented in the literature on action research programs, with trainees noting that action research empowers them to take a more holistic approach to instruction to understand the lived experiences of their students (Kosnik and Beck, 2000; Stevens and Kitchen, 2004; Goodnough, 2011). An understanding of student needs is an integral first step to problematizing during the action research process. The present module integrated case studies where recognition of students' struggles or problematic contextual factors was critical to progression in the "Design an Action Research Study" group exercise. Preparation to reflect upon collected data and reveal issues in even the esoteric facets of classroom dynamics-such as student difficulties and interactions-may help teachers to design instruction amenable to the learning needs of diverse students (Crawford-Garrett et al., 2015). Ostensibly, individuals could then account for the challenges (personal or otherwise) that they encounter as educators and work toward improving in target areas identified by their action research, thereby beginning the process of continuous professional development informed by classroom data (Cochran-Smith and Lytle, 1999).

\subsection{Methods to Address Potential Issues During Action Research}

When asked about the potential impediments to future involvement in action research, participants in our study focused mainly on logistical issues such as lack of time and resources. Participants suggested that they would form collaborations with university-based researchers, administrative faculty, or other teachers to address such challenges. Action research can increase teacher attitudes toward collaborative practice and dialogue between colleagues and, thus, is a viable solution to many of the logistical issues raised by our participants (Burbank and Kauchak, 2003). However, a subset of our participants also described their concerns about action research, specifically on survey use, sample size, and an overall fear of student resistance to participation in action research. Student resistance to unfamiliar, student-centered classroom practices are common-especially when their other classes perpetuate the use of didactic lecturing and objectivist, rather than constructivist, knowledge construction (Owens et al., 
2020). Likewise, students can often become "survey fatigued" and lack a sense of buy-in necessary for the researcher to obtain enough data to deduce the classroom practices that require reform (Porter et al., 2004).

While this may be the case, previous studies have indicated that the heightened interactivity associated with action research data collection can decrease student resistance and increase student cooperation (i.e., response rates) with respect to action research projects (Rogers et al., 2007). Classroom action research is unique in that data can be easily collected from the assignments that students complete as part of their regular coursework without the need to implement external assessments used solely to evaluate student outcomes. For those concerned about student resistance to action research activities, it can be beneficial to select or design assessments that possess the dual purpose of being both a research and teaching tool, which can serve to build student knowledge as well as obtain data to improve teaching and learning within the classroom (see Cooper et al., 2002, as an example). For assessments that may be more cumbersome or loosely aligned with curricular goals (e.g., assessments of affect or vocational goals), teachers can also offer extra credit to students to improve response rates (Luccasen and Thomas, 2014). While not explicitly addressed in our instructional module, future facilitators should plan to discuss methods to decrease student resistance to student-centered instruction and increase student participation in action research by way of informing participants of the benefits of active learning, assessment design, and how to equitably offer research incentives (see Goodman et al., 2015; Tharayil et al., 2018, for review).

\subsection{For Practitioners and Educators Looking to Facilitate ARPD}

Despite the success of this intervention in improving participants' knowledge of and affect toward action research, we, in no way, are suggesting this module is a panacea for ARPD. By design, we structured the action research module as a concise, three-session intervention to maximize scalability and promote its deployment in a variety of contexts. For the school administrator who intends to motivate teachers to engage in action research, the module can be completed in a series of 60-min sessions over three weeks, as was done in this study. This brief yet effective module can, likewise, be implemented alongside other interventions such as at the beginning of teacher education courses, internships in action research, or degree-granting programs at the graduate and undergraduate levels. As evidenced by participants' positive attitudes toward data use, the module provides an efficient scaffold upon which to build on teachers' quantitative and qualitative data literacy and, thus, can be implemented as a precursor to more sophisticated instruction in data literacy (see, as examples, Reeves and Honig, 2015; Dunlap and Piro, 2016). Furthermore, instructors of teacher research courses may be interested in implementing the module at the beginning of their courses to introduce their students to concepts of action research methodologies while improving upon students' related affective dispositions. In consideration of the resources of individual schools and school districts, such as the availability of support and time, the module is openly-available (see Supplementary Appendices S1.1-1.3) and low-cost and, therefore, can likely be effectively implemented across a diversity of learning environments (Soneral and Wyse, 2017).

\section{DATA AVAILABILITY STATEMENT}

The datasets presented in this article are not readily available because the approved study protocol and consent form explicitly state that data will not be shared with external parties except in instances where the research team is required to do so by law. Requests to access the datasets should be directed to Jeffrey Olimpo, jtolimpo@utep.edu.

\section{ETHICS STATEMENT}

The studies involving human participants were reviewed and approved by The University of Texas at El Paso Institutional Review Board. The patients/participants provided their written informed consent to participate in this study.

\section{AUTHOR CONTRIBUTIONS}

D.E., R.L.A., and J.T.O. contributed to the conception and design of the study. D.E. and J.T.O. led all data collection and analysis efforts with input from R.L.A. All authors were responsible for writing and revising sections of the manuscript. All authors read through and approved of the final draft of the manuscript submitted for consideration in Frontiers.

\section{FUNDING}

Research reported in this publication was supported, in part, by NIGMS/NIH Award Numbers RL5GM118969, TL4GM118971, and UL1GM118970.

\section{ACKNOWLEDGMENTS}

We are indebted to each of the individuals who participated in this action research module; their responsiveness and willingness to participate ultimately aided in our understanding of pre- and in-service educators' knowledge of and attitudes toward action research.

\section{SUPPLEMENTARY MATERIAL}

The Supplementary Material for this article can be found online at: https://www.frontiersin.org/articles/10.3389/feduc.2021.754097/ full\#supplementary-material 


\section{REFERENCES}

Adelman, C. (1993). Kurt Lewin and the Origins of Action Research. Educ. Action. Res. 1 (1), 7-24. doi:10.1080/0965079930010102

Aguinis, H. (1993). Action Research and Scientific Method: Presumed Discrepancies and Actual Similarities. J. Appl. Behav. Sci. 29 (4), 416-431. doi:10.1177/0021886393294003

Allen, J. P., Pianta, R. C., Gregory, A., Mikami, A. Y., and Lun, J. (2011). An Interaction-Based Approach to Enhancing Secondary School Instruction and Student Achievement. Science 333 (6045), 1034-1037. doi:10.1126/ science. 1207998

Altrichter, H., Posch, P., and Somekh, B. (1993). Teachers Investigate Their Work: An Introduction to the Methods of Action Research. London, UK: Psychology Press.

Atay, D. (2006). Teachers' Professional Development: Partnerships in Research. Electron. J. English as a Second Lang. 10 (2), 1-14.

Bates, R. (2005). On the Future of Teacher Education: Challenges, Context and Content. J. Edu. Teach. 31 (4), 301-305. doi:10.1080/02607470500280159

Bendtsen, M., Eklund, G., Forsman, L., and Pörn, M. (2019). Student Teachers' Experiences of Action Research-Based Projects: Two Cases within Pre-service Teacher Education in Finland. Educational Action Research, 1-15. doi:10.1080/ 09650792.2019.1684969

Buczynski, S., and Hansen, C. B. (2010). Impact of Professional Development on Teacher Practice: Uncovering Connections. Teach. Teach. Edu. 26 (3), 599-607. doi:10.1016/j.tate.2009.09.006

Burbank, M. D., and Kauchak, D. (2003). An Alternative Model for Professional Development: Investigations into Effective Collaboration. Teach. Teach. Edu. 19 (5), 499-514. doi:10.1016/s0742-051x(03)00048-9

Burkhard, R. A. (2005). "Towards a Framework and a Model for Knowledge Visualization: Synergies between Information and Knowledge Visualization," in Knowledge and Information Visualization (Berlin, Heidelberg: Springer), 238-255. doi:10.1007/11510154_13

Campbell, C., and Levin, B. (2009). Using Data to Support Educational Improvement. Educ. Asse Eval. Acc. 21 (1), 47-65. doi:10.1007/s11092-0089063-x

Capobianco, B. M., and Feldman, A. (2010). Repositioning Teacher Action Research in Science Teacher Education. J. Sci. Teach. Edu. 21 (8), 909-915. doi:10.1007/s10972-010-9219-7

Carboni, L. W., Wynn, S. R., and McGuire, C. M. (2007). Action Research with Undergraduate Preservice Teachers: Emerging/merging Voices. Action. Teach. Edu. 29 (3), 50-59. doi:10.1080/01626620.2007.10463460

Caro-Bruce, C., and Zeichner, K. (1998). Classroom Action Research: The Nature and Impact of an Action Research Professional Development Program in One Urban School District. Final Report. Madison Metropolitan School District. Available at: http://www.madison.k12.wi.us/sod/car/carspencerreport.html (December 15, 2021).

Carr, W., and Kemmis, S. (1986). Becoming Critical: Education Knowledge and Action Research. Brisbane, QLD: Routledge.

Carr, W. (1994). Whatever Happened to Action Research. Educ. Action. Res. 2 (3), 427-436. doi:10.1080/0965079940020310

Castro-Garcés, A. Y., and Martínez Granada, L. (2016). The Role of Collaborative Action Research in Teachers' Professional Development. Profile Issues Teach. Prof. Dev. 18 (1), 39-54.

Carver-Thomas, D., and Darling-Hammond, L. (2017). Teacher Turnover: Why It Matters and What We Can Do about It. Learning Policy Institute. Available at: https://files.eric.ed.gov/fulltext/ED606805.pdf (Accessed December 15, 2021).

Cherryholmes, C. H. (1992). Notes on Pragmatism and Scientific Realism. Educ. Res. 21 (6), 13-17. doi:10.3102/0013189x021006013

Chesnut, S. R., and Cullen, T. A. (2014). Effects of Self-Efficacy, Emotional Intelligence, and Perceptions of Future Work Environment on Preservice Teacher Commitment. The Teach. Educator 49 (2), 116-132. doi:10.1080/ 08878730.2014.887168

Chin, E. T., Lin, Y. C., Ko, Y. T., Chien, C. T., and Tuan, H. L. (2006). “Ollaborative Action Research on Implementing Inquiry-Based Instruction in an Eighth Grade Mathematics Class: An Alternative Mode for Mathematics Teacher Professional Development," in Proceedings 30th Conference of the International Group for the Psychology of Mathematics Education. Editor
J. Novotná, H. Moraová, M. Krátká, and N. Stehlíková (Prague, Czechia: PME) 305, 305-312.

Clarke, J., Dede, C., Ketelhut, D. J., and Nelson, B. (2006). A Design-Based Research Strategy to Promote Scalability for Educational Innovations. Educ. Tech. 46 (3), $27-36$.

Clift, R., Veal, M. L., Johnson, M., and Holland, P. (1990). Restructuring Teacher Education through Collaborative Action Research. J. Teach. Edu. 41 (2), 52-62. doi:10.1177/002248719004100207

Cochran-Smith, M., and Lytle, S. L. (1999). The Teacher Research Movement: A Decade Later. Educ. Res. 28 (7), 15-25. doi:10.3102/0013189x028007015

Cooper, B. C., Shepardson, D. P., and Harber, J. M. (2002). Assessments as Teaching and Research Tools in an Environmental Problem-Solving Program for In-Service Teachers. J. Geosci. Edu. 50 (1), 64-71. doi:10.5408/ 1089-9995-50.1.64

Corey, S. M. (1953). Action Research to Improve School Practices. Teachers Co: Bureau of Publications.

Crawford-Garrett, K., Anderson, S., Grayson, A., and Suter, C. (2015). Transformational Practice: Critical Teacher Research in Pre-service Teacher Education. Educ. Action. Res. 23 (4), 479-496. doi:10.1080/ 09650792.2015.1019902

Crookes, G., and Chandler, P. M. (2001). Introducing Action Research into the Education of Postsecondary Foreign Language Teachers. Foreign Lang. Ann. 34 (2), 131-140. doi:10.1111/j.1944-9720.2001.tb02818.x

Dang, T. K. A. (2013). Identity in Activity: Examining Teacher Professional Identity Formation in the Paired-Placement of Student Teachers. Teach. Teach. Edu. 30, 47-59. doi:10.1016/j.tate.2012.10.006

Darling-Hammond, L. (2008). Teacher Learning that Supports Student Learning. Teach. Intelligence 2 (1), 91-100.

Dassa, L., and Nichols, B. (2020). Making the Move: Empowering Student Teachers as Teacher Researchers. Teach. Educator 55 (3), 1-16. doi:10.1080/ 08878730.2020 .1713948

Dewey, J. (1905). The Realism of Pragmatism. J. Philos. Psychol. Scientific Methods 2 (12), 324-327. doi:10.2307/2010861

Dunlap, K., and Piro, J. S. (2016). Diving into Data: Developing the Capacity for Data Literacy in Teacher Education. Cogent Edu. 3 (1), 1132526. doi:10.1080/ 2331186x.2015.1132526

Eagleton, T., and Anderson, P. (1985). Marxism, Structuralism, and PostStructuralism. Diacritics 15 (4), 2. doi:10.2307/464931

Elliot, J., and Adelman, C. (1976). Innovation at the Classroom Level: A Case Study of the Ford Teaching ProjectUnit 28 Open University Course, E203 Curriculum Design and Development. Milton Keynes, England: Open University Press.

Eraut, M. (1994). Developing Professional Knowledge and Competence. London, UK: Psychology Press.

Faikhamta, C., and Clarke, A. (2015). Thai Pre-service Science Teachers Engaging Action Research during Their Fifth Year Internship. Asia Pac. J. Edu. 35 (2), 259-273. doi:10.1080/02188791.2013.860011

Flowers, N., and Carpenter, D. M. H. (2009). You Don't Have to Be a Statistician to Use Data: A Process for Data-Based Decision Making in Schools. Phi Delta Kappan 91 (2), 64-67. doi:10.1177/003172170909100214

Frankham, J., and Howes, A. (2006). Talk as Action in 'collaborative Action Research': Making and Taking Apart Teacher/researcher Relationships. Br. Educ. Res. J. 32 (4), 617-632. doi:10.1080/01411920600775324

Freeman, S., Eddy, S. L., McDonough, M., Smith, M. K., Okoroafor, N., Jordt, H., et al. (2014). Active Learning Increases Student Performance in Science, Engineering, and Mathematics. Proc. Natl. Acad. Sci. U S A. 111 (23), 8410-8415. doi:10.1073/pnas.1319030111

Fueyo, V., and Neves, A. (1995). Preservice Teacher as Researcher: A Research Context for Change in the Heterogeneous Classroom. Action. Teach. Edu. 16 (4), 39-49. doi:10.1080/01626620.1995.10463217

Garcia, E., and Weiss, E. (2019). "The Teacher Shortage Is Real, Large and Growing, and Worse Than We Thought. The First Report," in The Perfect Storm in the Teacher Labor Market" Series (Economic Policy Institute). Available at: https://files.eric.ed.gov/fulltext/ED598211.pdf (December 15, 2021)

Gelderblom, G., Schildkamp, K., Pieters, J., and Ehren, M. (2016). Data-based Decision Making for Instructional Improvement in Primary Education. Int. J. Educ. Res. 80, 1-14. doi:10.1016/j.ijer.2016.07.004 
Gelfuso, A., Dennis, D. V., and Parker, A. (2015). Turning Teacher Education Upside Down: Enacting the Inversion of Teacher Preparation through the Symbiotic Relationship of Theory and Practice. Prof. Educator 39 (2), n2.

Ginns, I., Heirdsfield, A., Atweh, B., and Watters, J. J. (2001). Beginning Teachers Becoming Professionals through Action Research. Educ. Action. Res. 9 (1), 111-133. doi:10.1080/09650790100200140

Gitlin, A., Barlow, L., Burbank, M. D., Kauchak, D., and Tracy Stevens, T. (1999). Preservice Teachers' Thinking on Research: Implications for Inquiry Oriented Teacher Education. Teach. Teach. Edu. 15 (7), 753-769. doi:10.1016/s0742-051x(99)00015-3

Goodman, J., Anson, R., and Belcheir, M. (2015). The Effect of Incentives and Other Instructor-Driven Strategies to Increase Online Student Evaluation Response Rates. Assess. Eval. Higher Edu. 40 (7), 958-970. doi:10.1080/ 02602938.2014.960364

Goodnough, K. (2011). Examining the Long-term Impact of Collaborative Action Research on Teacher Identity and Practice: the Perceptions of K-12 Teachers. Educ. Action. Res. 19 (1), 73-86. doi:10.1080/09650792.2011.547694

Goodnough, K. (2003). Facilitating Action Research in the Context of Science Education: Reflections of a university Researcher. Educ. Action. Res. 11 (1), 40-63. doi:10.1080/09650790300200203

Gore, J. M., and Zeichner, K. M. (1991). Action Research and Reflective Teaching in Preservice Teacher Education: A Case Study from the United States. Teach. Teach. Edu. 7 (2), 119-136. doi:10.1016/0742-051x(91)90022-h

Gray, J., and Campbell-Evans, G. (2002). Beginning Teachers as TeacherResearchers. Ajte 27 (1), 4. doi:10.14221/ajte.2002v27n1.4

Hagevik, R., Aydeniz, M., and Rowell, C. G. (2012). Using Action Research in Middle Level Teacher Education to Evaluate and Deepen Reflective Practice. Teach. Teach. Edu. 28 (5), 675-684. doi:10.1016/j.tate.2012.02.006

Hains, B. J., and Smith, B. (2012). Student-centered Course Design: Empowering Students to Become Self-Directed Learners. J. Experiential Edu. 35 (2), 357-374. doi:10.1177/105382591203500206

Halim, L., Meerah, T. S. M., and Buang, N. A. (2010). Developing Pre-service Science Teachers' Pedagogical Content Knowledge through Action Research. Proced. - Soc. Behav. Sci. 9, 507-511. doi:10.1016/j.sbspro.2010.12.188

Hansen, J. M., and Nalder-Godfrey, N. (2004). The Power of Action Research, Technology and Teacher Education. Comput. Schools 21 (1-2), 43-57. doi:10.1300/j025v21n01_04

Healy, K. (2001). Participatory Action Research and Social Work. Int. Soc. Work 44 (1), 93-105. doi:10.1177/002087280104400108

Henderson, C., and Dancy, M. H. (2011). "Increasing the Impact and Diffusion of STEM Education Innovations," in Invited Paper for the National Academy of Engineering, Center for the Advancement of Engineering Education Forum (Impact and Diffusion of Transformative Engineering Education Innovations). Available at: https://www.nae.edu/File.aspx?id $=36304$ (December 15, 2021).

Hillman, N. W. (2016). Geography of College Opportunity. Am. Educ. Res. J. 53 (4), 987-1021. doi:10.3102/0002831216653204

Holm, D. T., Hunter, K., and Welling, J. (1999). Supporting Systematic Change through Action Research. ERIC Clearinghouse. Available at: https://files.eric.ed. gov/fulltext/ED429957.pdf (December 15, 2021).

Huxham, C., and Vangen, S. (2003). Researching Organizational Practice through Action Research: Case Studies and Design Choices. Organizational Res. Methods 6 (3), 383-403. doi:10.1177/1094428103254454

Jakhelln, R., and Pörn, M. (2019). Challenges in Supporting and Assessing Bachelor's Theses Based on Action Research in Initial Teacher Education. Educ. Action. Res. 27 (5), 726-741. doi:10.1080/09650792.2018.1491411

Katz, L. G. (1972). Developmental Stages of Preschool Teachers. Elem. Sch. J. 73 (1), 50-54. doi:10.1086/460731

Kemmis, S., McTaggart, R., and Nixon, R. (2013). The Action Research Planner: Doing Critical Participatory Action Research. Springer Science \& Business Media.

Kemmis, S. (2010). What Is to Be Done? the Place of Action Research. Educ. Action. Res. 18 (4), 417-427. doi:10.1080/09650792.2010.524745

Kennedy-Clark, S., Eddles-Hirsch, K., Eddles-Hirsch, K., Francis, T., Cummins, G., Ferantino, L., et al. (2018). Developing Pre-service Teacher Professional Capabilities through Action Research. Ajte 43 (9), 39-58. doi:10.14221/ajte.2018v43n9.3

Kosnik, C., and Beck, C. (2000). The Action Research Process as a Means of Helping Student Teachers Understand and Fulfil the Complex Role of the Teacher. Educ. Action. Res. 8 (1), 115-136. doi:10.1080/09650790000200107
Kotsopoulos, D., Mueller, J., and Buzza, D. (2012). Pre-service Teacher Research: An Early Acculturation into a Research Disposition. J. Edu. Teach. 38 (1), 21-36. doi:10.1080/02607476.2012.643653

Lattimer, H. (2012). Action Research in Pre-service Teacher Education: Is There Value Added. ie: Inq. Educ. 3 (1), 5.

Levin, B. B., and Rock, T. C. (2003). The Effects of Collaborative Action Research on Preservice and Experienced Teacher Partners in Professional Development Schools. J. Teach. Edu. 54 (2), 135-149. doi:10.1177/0022487102250287

Lewin, K. (1944a). The Dynamics of Group Action. Educ. Leadersh. 1 (4), 195-200. Lewin, K. (1944b). A Research Approach to Leadership Problems. J. Educ. Sociol. 17 (7), 392-398. doi:10.2307/2262546

Lewin, K. (1946). Action Research and Minority Problems. J. Soc. Issues 2 (4), 34-46. doi:10.1111/j.1540-4560.1946.tb02295.x

Lewin, K., and Lippitt, R. (1938). An Experimental Approach to the Study of Autocracy and Democracy: A Preliminary Note. Sociometry 1 (3/4), 292-300. doi:10.2307/2785585

Lewin, K., Lippitt, R., and White, R. K. (1939). Patterns of Aggressive Behavior in Experimentally Created "Social Climates". J. Soc. Psychol. 10 (2), 269-299. doi:10.1080/00224545.1939.9713366

Looi, C. K., Hung, D., and Tan, L. (2006). Linking the Learning Sciences to Teacher Education: Teachers' Beliefs, Professional Development, and Scalability Issues. Educ. Tech. 46 (3), 22-26.

Luccasen, R. A., III, and Thomas, M. K. (2014). Monetary Incentives versus Class Credit: Evidence from a Large Classroom Trust experiment. Econ. Lett. 123 (2), 232-235. doi:10.1016/j.econlet.2014.02.012

Markham, K. M., Mintzes, J. J., and Jones, M. G. (1994). The Concept Map as a Research and Evaluation Tool: Further Evidence of Validity. J. Res. Sci. Teach. 31 (1), 91-101. doi:10.1002/tea.3660310109

Markic, S., and Eilks, I. (2006). Cooperative and Context-Based Learning on Electrochemical Cells in Lower Secondary Chemistry: A Project of Participatory Action Research. Sci. Edu. Int. 17 (4), 253-273.

McDonough, K. (2006). Action Research and the Professional Development of Graduate Teaching Assistants. Mod. Lang. J. 90 (1), 33-47. doi:10.1111/j.15404781.2006.00383.x

Medwell, J., and Wray, D. (2014). Pre-service Teachers Undertaking Classroom Research: Developing Reflection and Enquiry Skills. J. Edu. Teach. 40 (1), 65-77. doi:10.1080/02607476.2013.864018

Mills, G. E. (2000). Action Research: A Guide for the Teacher Researcher. Upper Saddle River, NJ: Prentice-Hall.

Mitchell, S. N., Reilly, R. C., and Logue, M. E. (2009). Benefits of Collaborative Action Research for the Beginning Teacher. Teach. Teach. Edu. 25 (2), 344-349. doi:10.1016/j.tate.2008.06.008

Mitton Kukner, J., Munroe, E., and Graham, D. (2015). The Challenge of Differing Perspectives Surrounding Grades in the Assessment Education of Pre Service Teachers. Cjhe 45 (4), 322-342. doi:10.47678/cjhe.v45i4.184403

Mojavezi, A., and Tamiz, M. P. (2012). The Impact of Teacher Self-Efficacy on the Students' Motivation and Achievement. Theor. Pract. Lang. Stud. 2 (3), 483-491. doi:10.4304/tpls.2.3.483-491

Morales, M. P. E., Abulon, E. L. R., Soriano, P. R., David, A. P., Hermosisima, M. V. C., and Gerundio, M. G. (2016). Examining Teachers' conception of and Needs on Action Research. Issues Educ. Res. 26 (3), 464.

Moran, M. J. (2007). Collaborative Action Research and Project Work: Promising Practices for Developing Collaborative Inquiry Among Early Childhood Preservice Teachers. Teach. Teach. Edu. 23 (4), 418-431. doi:10.1016/ j.tate.2006.12.008

Munten, G., Van Den Bogaard, J., Cox, K., Garretsen, H., and Bongers, I. (2010). Implementation of Evidence-Based Practice in Nursing Using Action Research: a Review. Worldviews Evid. Based Nurs. 7 (3), 135-157. doi:10.1111/j.17416787.2009.00168.x

Nair, A., Malhotra, M. K., and Ahire, S. L. (2011). Toward a Theory of Managing Context in Six Sigma Process-Improvement Projects: An Action Research Investigation. J. Operations Manage. 29 (5), 529-548. doi:10.1016/ j.jom.2010.11.014

National Commission on Teaching and America's Future (2003). No Dream Denied: A Pledge to America's Children Summary Report. Washington, DC.

National Council for Accreditation of Teacher Education (NCATE) (2010). "Blue Ribbon Panel of Clinical Preparation and Partnerships for Improved Children 
Learning," in Transforming Teacher Education through Clinical Practice: A National Strategy to Prepare Effective Teachers (Washington, DC.

National Research Council (2012). A Framework for K-12 Science Education: Practices, Crosscutting Concepts, and Core Ideas. Washington, DC: National Academies Press.

NGSS Lead States (2013). Next Generation Science Standards: For States, by States. Washington, DC: The National Academies Press.

Novick, L. R. (2001). Spatial Diagrams: Key Instruments in the Toolbox for Thought. Psychol. Learn. Motiv. Adv. Res. Theor. 40, 279-325.

O'Connor, K. A., Greene, H. C., and Anderson, P. J. (2006). Action Research: A Tool for Improving Teacher Quality and Classroom Practice. [Paper presentation]. San Francisco, CA: American Educational Research Association Annual Meeting. April 7.

Odhiambo, E. (2010). Classroom Research: A Tool for Preparing Pre-service Teachers to Become Reflective Practitioners, 4. Journal of Instructional Pedagogies. Available at: https://files.eric.ed.gov/fulltext/EJ1096958.pdf (December 15, 2021).

Olimpo, J. T., and Esparza, D. (2020). "Active Learning and Conceptual Understanding in Biology," in Active Learning in College Science. Editors J. Mintzes and E. Walter (Springer International Publishing), 43-57. doi:10.1007/978-3-030-33600-4_4

Oquist, P. (1978). The Epistemology of Action Research. Acta Sociologica 21 (2), 143-163. doi:10.1177/000169937802100204

Owens, D. C., Sadler, T. D., Barlow, A. T., and Smith-Walters, C. (2020). Student Motivation from and Resistance to Active Learning Rooted in Essential Science Practices. Res. Sci. Educ. 50 (1), 253-277. doi:10.1007/s11165-0179688-1

Porter, S. R., Whitcomb, M. E., and Weitzer, W. H. (2004). Multiple Surveys of Students and Survey Fatigue. New Dir. Institutional Res. 2004 (121), 63-73. doi:10.1002/ir.101

Price, J. N. (2001). Action Research, Pedagogy and Change: The Transformative Potential of Action Research in Pre-service Teacher Education. J. Curriculum Stud. 33 (1), 43-74. doi:10.1080/00220270118039

Qing-li, H., Torres, M. N., and Shi-Ji, F. (2019). Collaborative Action Research for Preparing Teachers as Reflective Practitioners. Syst. Pract. Action. Res 32 (4), 411-427. doi:10.1007/s11213-018-9461-z

Reeves, T. D., and Honig, S. L. (2015). A Classroom Data Literacy Intervention for Pre-service Teachers. Teach. Teach. Edu. 50, 90-101. doi:10.1016/ j.tate.2015.05.007

Rock, T. C., and Levin, B. B. (2002). Collaborative Action Research Projects: Enhancing Preservice Teacher Development in Professional Development Schools. Teach. Edu. Q. 29 (1), 7-21.

Rogers, D., Bolick, C. M., Anderson, A., Gordon, E., Manfra, M. M., and Yow, J. (2007). "It's about the Kids": Transforming Teacher-Student Relationships through Action Research. The Clearing House: A J. Educ. Strateg. Issues Ideas 80 (5), 217-222. doi:10.3200/tchs.80.5.217-222

Sanford, N. (1976). "Whatever Happened to Action Research," in Experimenting with Organizational Life (Boston, MA: Springer), 19-32. doi:10.1007/978-14613-4262-5_3

Schulte, A. K. (2017). The Impacts of Preservice Action Research in a Rural Teaching Residency. J. Inq. Action. Edu. 9 (1), 5.

Shulman, L. S. (1986). Those Who Understand: Knowledge Growth in Teaching. Educ. Res. 15 (2), 4-14. doi:10.3102/0013189x015002004

Smith, J. J., Cheruvelil, K. S., and Auvenshine, S. (2013). Assessment of Student Learning Associated with Tree Thinking in an Undergraduate Introductory Organismal Biology Course. CBE Life Sci. Educ. 12 (3), 542-552. doi:10.1187/ cbe.11-08-0066

Smith, K., and Sela, O. (2005). Action Research as a Bridge between Pre-service Teacher Education and In-service Professional Development for Students and Teacher Educators. Eur. J. Teach. Edu. 28 (3), 293-310. doi:10.1080/ 02619760500269418

Soneral, P. A., and Wyse, S. A. (2017). A SCALE-UP Mock-Up: Comparison of Student Learning Gains in High- and Low-Tech Active-Learning Environments. CBE Life Sci. Educ. 16 (1), ar12. doi:10.1187/cbe.16-07-0228

Stevens, D., and Kitchen, J. (2004). Introducing Pre-service Teachers to Action Research. Ontario Action. Res. 7 (1). http://oar.nipissingu.ca/PDFS/ V711.pdf
Sutcher, L., Darling-Hammond, L., and Carver-Thomas, D. (2019). Understanding Teacher Shortages: An Analysis of Teacher Supply and Demand in the United States. epaa 27 (35), 35. doi:10.14507/epaa.27.3696

Taber, K. S. (2018). The use of Cronbach's Alpha When Developing and Reporting Research Instruments in Science Education. Res. Sci. Edu. 48 (6), 1273-1296

Taruc, P. W. (2016). Influence of Teachers' Beliefs and Attitude towards Action Research. Liceo J. Higher Edu. Res. 12 (2), 82-109. doi:10.7828/ ljher.v12i1.959

Tesch, R. (2013). Qualitative Research: Analysis Types and Software. New York, NY: Routledge.

Tharayil, S., Borrego, M., Prince, M., Nguyen, K. A., Shekhar, P., Finelli, C. J., et al. (2018). Strategies to Mitigate Student Resistance to Active Learning. Int. J. STEM Educ. 5 (1), 7. doi:10.1186/s40594-018-0102-y

Theobald, E. J., Hill, M. J., Tran, E., Agrawal, S., Arroyo, E. N., Behling, S., et al. (2020). Active Learning narrows Achievement Gaps for Underrepresented Students in Undergraduate Science, Technology, Engineering, and Math. Proc. Natl. Acad. Sci. U S A. 117 (12), 6476-6483. doi:10.1073/ pnas. 1916903117

Tversky, B. (2014). "Visualizing Thought," in Handbook of Human Centric Visualization (New York, NY: Springer), 3-40. doi:10.1007/978-1-46147485-2_1

Ulvik, M., and Riese, H. (2016). Action Research in Pre-service Teacher Education - a Never-Ending story Promoting Professional Development. Prof. Dev. Edu. 42 (3), 441-457. doi:10.1080/19415257.2014.1003089

Valanides, N., Nicolaidou, A., and Eilks, I. (2003). Twelfth Grade Students' Understanding of Oxidation and Combustion: Using Action Research to Improve Teachers' Practical Knowledge and Teaching Practice. Res. Sci. Technol. Edu. 21 (2), 159-175. doi:10.1080/0263514032000127211

Valli, L. (2000). Connecting Teacher Development and School Improvement: Ironic Consequences of a Preservice Action Research Course. Teach. Teach. Edu. 16 (7), 715-730. doi:10.1016/s0742-051x(00)00021-4

Van Geel, M., Keuning, T., Visscher, A. J., and Fox, J.-P. (2016). Assessing the Effects of a School-wide Data-Based Decision-Making Intervention on Student Achievement Growth in Primary Schools. Am. Educ. Res. J. 53 (2), 360-394. doi:10.3102/0002831216637346

Veenman, S. (1984). Perceived Problems of Beginning Teachers. Rev. Educ. Res. 54 (2), 143-178. doi:10.3102/00346543054002143

Vescio, V., Ross, D., and Adams, A. (2008). A Review of Research on the Impact of Professional Learning Communities on Teaching Practice and Student Learning. Teach. Teach. Edu. 24 (1), 80-91. doi:10.1016/ j.tate.2007.01.004

Wang, H., Hall, N. C., and Rahimi, S. (2015). Self-efficacy and Causal Attributions in Teachers: Effects on Burnout, Job Satisfaction, Illness, and Quitting Intentions. Teach. Teach. Edu. 47, 120-130. doi:10.1016/ j.tate.2014.12.005

Wastin, E., and Han, H. (2014). Action Research and Project Approach: Journey of an Early Childhood Pre-service Teacher and a Teacher Educator. Networks: Online J. Teach. Res. 16 (2), 7. doi:10.4148/2470-6353.1044

Willegems, V., Consuegra, E., Struyven, K., and Engels, N. (2017). Teachers and Pre-service Teachers as Partners in Collaborative Teacher Research: A Systematic Literature Review. Teach. Teach. Edu. 64, 230-245. doi:10.1016/ j.tate.2017.02.014

Wilson, K. J., and Rigakos, B. (2016). Scientific Process Flowchart Assessment (SPFA): A Method for Evaluating Changes in Understanding and Visualization of the Scientific Process in a Multidisciplinary Student Population. CBE Life Sci. Educ. 15 (4), ar63. doi:10.1187/cbe.15-10-0212

Winograd, K., and Evans, T. (1995). Preservice Elementary Teachers' Perceptions of an Action Research Assignment. Action. Teach. Edu. 17 (3), 13-22. doi:10.1080/01626620.1995.10463252

Womack, S. T. (1997). What Action Research Is: A Review of the Literature. Available at: https://files.eric.ed.gov/fulltext/ED414255.pdf.

Yan, C. (2017). 'You Never Know what Research Is like unless You've Done it!' Action Research to Promote Collaborative Student-Teacher Research. Educ. Action. Res. 25 (5), 704-719. doi:10.1080/09650792.2016.1245155

Yost, D. S. (2006). Reflection and Self-Efficacy: Enhancing the Retention of Qualified Teachers from a Teacher Education Perspective. Teach. Edu. Q. 33 (4), 59-76. 
Zagallo, P., McCourt, J., Idsardi, R., Smith, M. K., Urban-Lurain, M., Andrews, T. C., et al. (2019). Through the Eyes of Faculty: Using Personas as a Tool for Learner-Centered Professional Development. CBE Life Sci. Educ. 18 (4), ar62. doi:10.1187/cbe.19-06-0114

Zambo, D., and Zambo, R. (2007). Action Research in an Undergraduate Teacher Education Program: What Promises Does it Hold. Action. Teach. Edu. 28 (4), 62-74. doi:10.1080/01626620.2007.10463430

Zvauya, R., Purandare, S., Young, N., and Pallan, M. (2017). The Use of Mind Maps as an Assessment Tool in a Problem Based Learning Course. Ce 08 (11), 1782-1793. doi:10.4236/ce.2017.811122

Conflict of Interest: The authors declare that the research was conducted in the absence of any commercial or financial relationships that could be construed as a potential conflict of interest.
Publisher's Note: All claims expressed in this article are solely those of the authors and do not necessarily represent those of their affiliated organizations, or those of the publisher, the editors and the reviewers. Any product that may be evaluated in this article, or claim that may be made by its manufacturer, is not guaranteed or endorsed by the publisher.

Copyright (๑) 2022 Esparza, Lynch-Arroyo and Olimpo. This is an open-access article distributed under the terms of the Creative Commons Attribution License (CC BY).

The use, distribution or reproduction in other forums is permitted, provided the original author(s) and the copyright owner(s) are credited and that the original publication in this journal is cited, in accordance with accepted academic practice. No use, distribution or reproduction is permitted which does not comply with these terms. 